\title{
BONE MORPHOGENETIC PROTEINS: A NEW VISTA IN BONE REGENERATION
}

Muktevi Sreedhar ${ }^{1}$

\section{HOW TO CITE THIS ARTICLE:}

Muktevi Sreedhar. "Bone Morphogenetic Proteins: A New Vista in Bone Regeneration". Journal of Evolution of Medical and Dental Sciences 2014; Vol. 3, Issue 20, May 19; Page: 5448-5452,

DOI: $10.14260 /$ jemds/2014/2612

\begin{abstract}
Treatment of delayed union, malunion, and nonunion is a challenge to the orthopedic surgeons Apart from restoration of alignment and stable fixation, in many cases adjunctive measures such as bone-grafting or use of bone-graft substitutes are of paramount importance. Autologous bone remains the "gold standard" for stimulating bone repair and regeneration, but its availability may be limited and the procedure to harvest the material is associated with complications. Bone-graft substitutes can either substitute autologous bone graft or expand an existing amount of autologous bone graft. This review focuses on role of bone morphogenetic proteins in bone regeneration.
\end{abstract}

KEYWORDS: Bone regeneration, bone morphogenetic proteins.

INTRODUCTION: Advent in scientific research has improved the various treatment modalities available for the operating surgeons and has paved way for better treatment outcomes and thereby patient satisfaction. Orthopedic surgeons have a close encounter with large bone replacement areas either due to trauma or infections or many other causes and not always autografts are the choice.

Bone is unique of all the tissues in the in the vertebrate organism. When injured, it heals by formation of new bone. In contrast, most other tissues such as the heart muscle, voluntary muscles, liver, and the brain heal by replacement of connective tissue rather than the original tissue. Another interesting attribute of the bone is that the molecular and cellular processes that lead to the development of the skeletal structures within the embryo are very similar to the cascades that occur in the healing process in an injured bone. ${ }^{1}$

Bone Morphogenetic Proteins (BMPs) are a group of growth factors and cytokines which were originally discovered by their ability to induce formation of bone and cartilage, but are now considered to constitute a group of pivotal morphogenetic signals, orchestrating tissue architecture throughout the body ${ }^{2}$.The ability of devitalized bone, when implanted in an animal, to induce a cellular response resulting in new bone tissue formation has been known for decades. ${ }^{3}$ This unique activity was observed and researched extensively by an orthopedic surgeon, Dr. Marshall Urist. He subsequently demonstrated that this activity could be extracted from the organic component of bone using chaotropic agents, and that a protein or proteins were responsible for this activity. ${ }^{4,5} \mathrm{He}$ thus named this activity "bone morphogenetic protein."

Since this discovery, a wide range of allogeneic bone grafts has become available as a substitute or extender to autograft, yet with limited success. The goal of these allogeneic bone grafts was to offer the greatest amount of BMP available within the tissue, but these bone graft products are constrained by the small amount of BMPs found within the actual collagen matrix.

The advent of bone growth factors has been widely anticipated since their successful production using recombinant DNA technology. Bone morphogenetic proteins (BMPs) are an important class of bone growth factors. It appears that we are on the brink of tremendous advances 


\section{REVIEW ARTICLE}

in the use of bone growth factors as therapeutics, which will revolutionize how clinicians treat such problems. Bone contains a cocktail of growth factors including transforming growth factor beta (TGF$\beta$ platelet derived growth factor (PDGF), bone morphogenetic proteins (BMPs), insulin-like growth factors I and II (IGF-I and IGF-II) and fibroblast growth factors (FGFs). BMPs differ from other growth factors in that they are Osteoinductive.

STRUCTURE AND SYNTHESIS: BMPs consist of dimers that are interconnected by seven disulphide bonds, ${ }^{7}$ this dimerization is a prerequisite for bone induction. ${ }^{8}$ BMPs are active both as homodimer molecules that consist of two identical chains, and as a heterodimers consisting of two different chains. Fifteen BMPs have currently been identified.9,7,11

BMP's, are further divided into subfamilies according to their amino acid sequence similarities. BMPs-2 and -4 form one subgroup, BMPs- 5-8 form a second subgroup, and a third subgroup contains BMP-3 and GDF-10,12 a related growth factor. Members of each subgroup have shown osteoinductivity BMP-1 is not related to the BMP family.

It does not show osteoinductivity, ${ }^{13}$ and has recently been identified as procollagen-Cproteinase. ${ }^{14}$ BMPs are synthesized by osteoblasts as 400-500 amino acid peptides, each consisting of a leader sequence, a propeptide, and a mature osteoinductive domain at the carboxy-terminal. The mature domain of each BMP contains a region of seven conserved cysteine amino acids, six of which are involved in forming a characteristic structural motif: a cysteine-knot with two finger-like doublestranded sheets ${ }^{15}$

Dosage of BMP: It has been estimated that normal bone contains approximately $0.002 \mathrm{mg}$ of BMP per kilogram of pulverized bone. At a fracture site, presumably the BMP is released at a higher concentration because of the secretion by the transformed inflammatory cells into osteoprogenitor cells and upregulation of BMP from the released cytokines at the fracture site.

The exact concentration of the BMP at the fracture site as opposed to physiological concentration in the normal bone is unknown. The concentration required for ideal induced bone bridging in osseous defects depends on several factors. First is the state of the organism in the evolutionary scale. Additionally, the type of defect should be considered.

Apparently, the enhanced BMP released locally at the site of fracture is sufficient to induce bridging of the broken fragments if they are in apposition. Therefore, the use of BMP is seldom considered when treating straightforward long bone fractures. On the other hand, fractures in which there are critical segmental defects in the long bones do not heal spontaneously. They require adjuvant autograft or BMP for adequate healing. ${ }^{1}$

RECOMBINANT HUMAN BMP-2 IN ORTHOPAEDIC APPLICATIONS: Endogenous BMPs are typically found in the body at a concentration of less than $2 \mathrm{mg} / \mathrm{kg}$ in cortical bone. ${ }^{16}$ and are difficult to extract in sufficient quantities for clinical use. Recombinant human BMP-2 is highly osteoinductive. 17 In vitro studies show that mesenchymal stem cells incubated with rhBMP-2 have increased alkaline phosphatase activity and undergo matrix mineralisation. ${ }^{18,19}$ When implanted In vivo, rhBMP-2 induces osteoinduction by recruiting mesenchymal stem cells, then inducing the proliferation and differentiation of these cells into an osteoprogenitor lineage. The bone formed has exactly the same composition as bone elsewhere in the body. ${ }^{20}$ 
Early pre-clinical studies of postero lateral fusion showed that while rhBMP-2 plus ACS achieved fusion rates of $100 \%$ in lower animal models (rabbit and dog), 21,22 in higher animal models the ACS appeared to be compressed by muscle fibres, hampering bone formation. ${ }^{23}$

In particular, recombinant human bone morphogenetic proteins (rhBMPs) are being used with increasing frequency for spinal fusions because of their potent osteoinductive activities, which have been documented in multiple preclinical and clinical studies.10-17 With regard to spinal applications, Aryan and colleagues15 described a series of 15 patients who received rhBMP-2 as part of their treatment regimen for vertebral osteomyelitis and achieved solid fusions by 5 years with no evidence of recurrent infection.

As the biological pathways affected by BMPs continue to be elucidated, it is possible that indications for using rhBMP-2 may expand to include clinical situations such as fusion in the setting of active local surgical site infections. Bone morphogenetic proteins (BMPs) may have an important role in bone and cartilage formation, fracture healing and repair of other musculoskeletal tissues.

There are two BMPs clinically available: BMP-7 (also known as osteogenic protein-1 or OP-1) supplied by Stryker UK, which uses a bovine collagen carrier in granular form (OP-1 Putty in the US and Osigraft ${ }^{\circledR}$ in the UK), and rhBMP-2 supplied by Wyeth Research Ltd, which uses a collagen sponge carrier (InFUSE in the US and InductOs in the UK).

CONCLUSION: The capability of BMP to regenerate bone has been conclusively proven in a number of animal studies and off late human trials have also shown favorable outcomes with a few limitations. However, in the near future a larger number of clinical trials are to be undertaken to make this material a readily available regenerative material.

\section{REFERENCES}

1. Setti S Rengachary. Bone morphogenetic proteins: basic concepts. Neurosurg Focus 13 (6): Article 2, 2002.

2. Pundir A, Pundir S, Srinivas TS, Yeltiwar RK. Bone morphogenetic proteins: Role in periodontal regeneration. Indian Journal Of Dental Research And Review Oct 2011 - Mar 2012

3. Urist MR. Bone: Formation by autoinduction. Science 1965; 150: 893-9.

4. Urist MR, Iwata H, Ceccotti PL, et al. Bone morphogenesis in implants of insoluble bone gelatin. Proc Natl Acad Sci U S A 1973; 70: 3511-15.

5. Urist MR, Mikulski A, Lietze A. Solubilized and insolubilized bone morphogenetic protein. Proc Natl Acad Sci U S A 1979; 76: 1828-32.

6. Rebecca $\mathrm{H} \mathrm{Li}$, John M Wozney. Delivering on the promise of bone morphogenetic proteins. Trends in Biotechnology Vol.19; No.7. July 2001.

7. Wozney JM. Bone morphogenetic proteins. Progress in Growth Factor Research 1989; 1: 267-280.

8. Wozney JM, Rosen V, Celeste AJ, Mitsock LM, Whitters MJ, Kriz RW, Hewick RM, Wang EA. Novel regulators of bone formation: molecular clones and activities. Science 1988; 242: 1528-1534.

9. Wang EA, Rosen V, Cordes P, Hewick RM, Kriz MJ, Luxenberg DP, Sibley BS, Wozney JM. Purification and characterization of other distinct bone-inducing factors. Proceedings of the National Academy of Sciences of the USA 1988; 85: 9484-9488. 
10. King JA, Marker PC, Seung KJ, Kingsley DM. BMP5 and the molecular, skeletal, and soft-tissue alterations in short ear mice. Developmental Biology 1994; 166: 112-122.

11. Gitelman SE, Kobrin MS, Ye JQ, Lopez AR, Lee A, Derynck R. Recombinant Vgr-1/BMP-6expressing tumors induce fibrosis and endochondral bone formation in vivo. Journal of Cellular Biology 1994; 126: 1595-1609.

12. Cunningham NS, Jenkins NA, Gilbert DJ, Copeland NG, Reddi AH, Lee SJ. Growth/differentiation factor-10: a new member of the transforming growth factor-beta superfamily related to bone morphogenetic protein-3. Growth Factors 1995; 12: 99-109.

13. Takuwa Y, Ohse C, Wang EA, Wozney JM, Yamashita K. Bone morphogenetic protein-2 stimulates alkaline phosphatase activity and collagen synthesis in cultured osteoblastic cells, MC3T3-E1. Biochemical and Biophysical Research Communications 1991; 174: 96-101.

14. Hofbauer LC, Heufelder AE. Updating the metalloprotease nomenclature: bone morphogenetic protein 1 identified as procollagen C proteinase. European Journal of Endocrinology 1996; 135: 35-36.

15. Marek Szpalski, Robert Gunzburg. Recombinant human bone morphogenetic protein-2: A novel osteoinductive alternative to autogenous bone graft? Acta Orthop. Belg., 2005, 71, 133-148.

16. Prolo DJ, Rodrigo JJ. Contemporary bone graft physiology and surgery. Clin Orthop 1985; 200: 322-342.

17. Ludwig SC, Boden SD. Osteoinductive bone graft substitutes for spinal fusion: a basic science summary. Orthop Clin North Am 1999; 30: 635-645.

18. Cheng SL, Lou J, Wright NM et al. In vitro and in vivo induction of bone formation using a recombinant adenoviral vector carrying the human BMP-2 gene. Calcif Tissue Int 2001; 68; 8794.

19. Riew KD, Wright NM, Cheng S et al. Induction of bone formation using a recombinant adenoviral vector carrying the human BMP-2 gene in a rabbit spinal fusion model. Calcif Tissue Int 1998; 63: 357-360.

20. Valentin-Opran A, Wozney J, Csimma C et al. Clinical evaluation of recombinant human bone morphogenetic protein-2. Clin Orthop 2002; 395: 110-120.

21. Sandhu HS, Kanim LEA, Kabo JM et al. Effective doses of recombinant human bone morphogenetic protein-2 in experimental spinal fusion. Spine 1996; 21: 2115-2122.

22. Schimandle JH, Boden SD, Hutton WC. Experimental spinal fusion with recombinant human bone morphogenetic protein-2. Spine 1995; 20:1326-1337.

23. Martin GJ jr, Boden SD, Morone MA, Moskovitz PA. Posterolateral intertransverse process spinal arthrodesis with rhBMP-2 in a non-human primate: important lessons learned regarding dose, carrier, and safety. J Spinal Disord 1999; 12: 179-186. 


\section{REVIEW ARTICLE}

\section{AUTHORS:}

1. Muktevi Sreedhar

\section{PARTICULARS OF CONTRIBUTORS:}

1. Assistant Professor, Department of Orthopaedics, Kamineni Institute of Medical Sciences.

\section{NAME ADDRESS EMAIL ID OF THE} CORRESPONDING AUTHOR:

Dr. M. Sreedhar,

H. No. 8-133, J. P. Colony, Road No. 2, Patancher-502319, Medak District, Andhra Pradesh.

Email: drmuktevi@gmail.com

Date of Submission: 22/04/2014.

Date of Peer Review: 23/04/2014.

Date of Acceptance: 30/04/2014.

Date of Publishing: 15/05/2014. 